\title{
Microarray comparative genomic hybridisation analysis of intraocular uveal melanomas identifies distinctive imbalances associated with loss of chromosome 3
}

\author{
S Hughes', BE Damato ${ }^{2}$, I Giddings ${ }^{3}$, PS Hiscott ${ }^{2}$, J Humphreys ${ }^{3}$ and RS Houlston ${ }^{*, I}$ \\ 'Section of Cancer Genetics, Institute of Cancer Research, Sutton, SM2 5NG, UK; ' Liverpool Ocular Oncology Center, Royal Liverpool University Hospital, \\ Liverpool L7 8XP, UK; ${ }^{3}$ Section of Molecular Carcinogenesis, Institute of Cancer Research, Sutton SM2 5NG, UK
}

\begin{abstract}
Defining regions of genomic imbalance can identify genes involved in tumour development. Conventional cytogenetics has identified several nonrandom copy number alterations (CNA) in uveal melanomas (UVM), which include monosomy 3, chromosome 6 abnormalities and gain of $8 \mathrm{q}$. To gain further insight into the CNAs and define the regions involved more precisely we analysed 18 primary UVMs using I Mb BAC microarray comparative genomic hybridisation (CGH). Our analysis showed that the most common genomic imbalances were 8q gain (78\%), 6p gain (67\%) and monosomy 3 (56\%). Two distinct CGH profiles could be delineated on the basis of the chromosome 3 status. The most common genetic changes in monosomy 3 tumours, in our study, were gain of $8 q|1.21-q 24.3,6 p 25.1-p 21.2,2| q 21.2-q 21.3$ and $21 q 22.13-q 22.3$ and loss of $|p 36.33-p 34.3| p ,3||-.p 21.2,6 q \mid 6.2-q 25.3$ and 8p23.3-pll.23. In contrast, disomy 3 tumours showed recurrent gains of only 6p25.3-p22.3 and 8q23.2-q24.3. Our approach allowed definition of the smallest overlapping regions of imbalance, which may be important in the development of UVM. British Journal of Cancer (2005) 93, II91-1 196. doi:I0.1038/sj.bjc.6602834 www.bjcancer.com
\end{abstract} Published online 25 October 2005

(C) 2005 Cancer Research UK

Keywords: uveal melanoma; array $\mathrm{CGH}$; regions of imbalance

Uveal melanomas (UVM) are the most common primary intraocular malignant tumours (Stang et al, 2005). Despite successful treatment of the primary tumour approximately $50 \%$ of patients develop metastatic disease, which is usually unresponsive to chemotherapy and invariably fatal (Bergman et al, 2003). Tumours most commonly arise in the choroids with less than $10 \%$ developing in the iris and ciliary body. UVMs are classified as spindle, epithelioid, or mixed according to their histological appearance (McLean et al, 2004).

Cytogenetic analyses and allelic imbalance studies have identified a number of recurrent chromosomal aberrations in UVM, including loss of chromosome 3, and copy number alterations (CNA) on chromosomes 6 and 8 (Tschentscher et al, 2000; Aalto et al, 2001; Naus et al, 2001).

In this study we have, for the first time sought to further refine the regions of chromosomal imbalance in UVM by analysing tumours using BAC microarray CGH. The resolution of arrays in identifying regions of chromosome imbalance is dependent upon the number and distribution of the clones. The arrays used in this study were based on a previously reported BAC clone set (Fiegler et $a l, 2003$ ) and we validated the detection of CNAs in a series of sex mismatch experiments through which incorrectly annotated clones were identified and excluded from subsequent analyses. The median coverage across the genome for the 3421 BACs included on the array was one clone every $1 \mathrm{Mb}$ (range $500 \mathrm{~Kb}-4.5 \mathrm{Mb}$,

*Correspondence: RS Houlston; E-mail: richard.houlston@icr.ac.uk Received 8 June 2005; revised 26 August 2005; accepted 20 September 2005; published online 25 October 2005 excluding BACs spanning centromeres). Detection of copy number changes is influenced by factors including tumour heterogeneity and contamination with infiltrating lymphocytes. In this study, we restricted our analysis to tumours that have been verified to contain less than $10 \%$ normal cell contamination. This approach has allowed for the definition of chromosomal regions that represent the smallest overlapping regions of imbalance (SORI), which are likely to harbour oncogenes or tumour suppressor genes.

\section{MATERIALS AND METHODS}

\section{Patient samples}

The tumour samples used in this study (Table 1) were obtained from different patients attending the Liverpool Ocular Oncology Centre between 1994 and 1997. All tumours were primary lesions and the diagnosis of UVM was histologically confirmed in all cases. In the nine patients alive on the 15 August 2005, the follow-up had a median of 6.97 years, exceeding 1 and 5 years in 15 patients and 10 patients, respectively. Samples were obtained with informed consent and Local Ethical Review Board approval in accordance with the tenets of the Declaration of Helsinki.

\section{Array CGH}

DNA was extracted from tumours using the QIAamp DNA Micro Kit (Qiagen, UK) and the DNA concentration was determined using the RediPlate 96 PicoGreen dsDNA Quantitation Kit 
Table I Clinico-pathological characteristics of patients analysed

\begin{tabular}{|c|c|c|c|c|c|c|}
\hline Tumour ID & Gender & $\begin{array}{c}\text { Age at diagnosis } \\
\text { (years) }\end{array}$ & Tumour size $(\mathrm{mm})$ & Cell type & $\begin{array}{l}\text { Metastatic death } \\
\text { from UVM }\end{array}$ & $\begin{array}{l}\text { Chromosome } 3 \\
\text { status }\end{array}$ \\
\hline 15 & Male & 49 & 18.0 & Mixed & + & Monosomy \\
\hline 18 & Male & 72 & 18.5 & Mixed & + & Monosomy \\
\hline 24 & Male & 73 & 17.5 & Mixed & + & Monosomy \\
\hline 33 & Male & 50 & 12.8 & Mixed & - & Disomy \\
\hline 40 & Male & 86 & 18.8 & Mixed & + & Monosomy \\
\hline 41 & Male & 29 & 11.8 & Mixed & - & Disomy \\
\hline 43 & Male & 67 & 18.4 & Mixed & + & Monosomy \\
\hline 44 & Male & 72 & 17.9 & Mixed & $-{ }^{a}$ & Monosomy \\
\hline 53 & Male & 42 & 20.9 & Spindle cell & - & Monosomy \\
\hline 55 & Male & 67 & 14.2 & Spindle cell & + & Disomy \\
\hline 59 & Male & 57 & 15.8 & Mixed & - & Disomy \\
\hline 64 & Female & 42 & 16.2 & Mixed & - & Monosomy \\
\hline 67 & Female & 65 & 19.7 & Mixed & - & Monosomy \\
\hline 69 & Female & 51 & 13.6 & Mixed & - & Disomy \\
\hline 75 & Male & 54 & 22.2 & Mixed & - & Disomy \\
\hline 76 & Male & 57 & 18.4 & Mixed & + & Monosomy \\
\hline 79 & Female & 81 & 14.2 & Spindle cell & $-{ }^{b}$ & Disomy \\
\hline 81 & Male & 52 & 12.0 & Mixed & - & Disomy \\
\hline
\end{tabular}

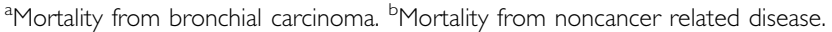

Table 2 Overview of genetic changes

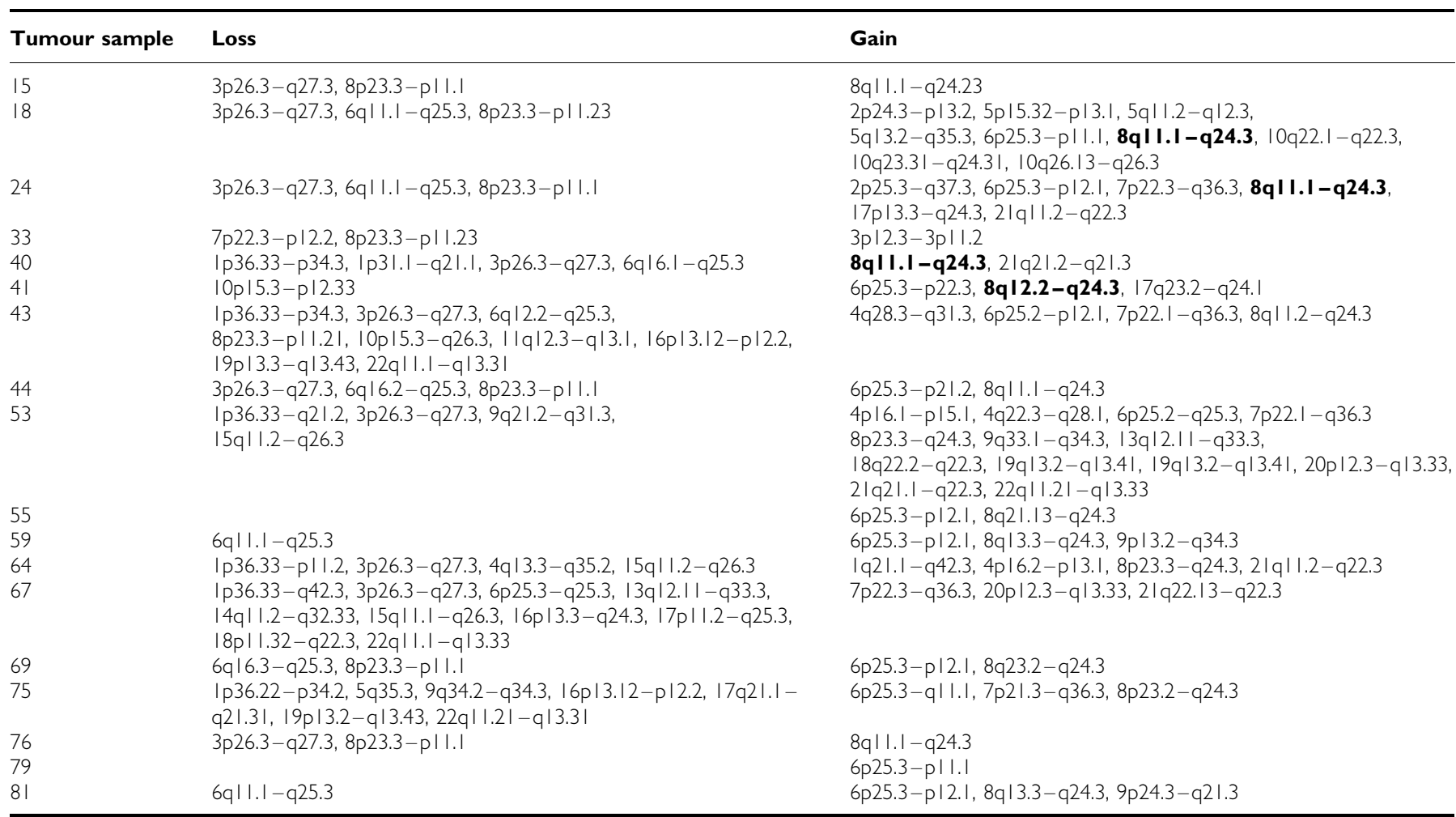

Highly amplified regions in bold.

(Invitrogen, UK). Both procedures were performed following manufacturers instructions. The genomic DNA arrays used in these experiments were obtained from the Cancer Research UK DNA Microarray Facility and consist of 3421 BAC and PAC clones, which provide an average genomic resolution of $1 \mathrm{Mb}$. Reference DNA (Promega, UK) and test DNA were labelled separately with Cy3 and Cy5 dyes (Amersham, UK) using the BioPrime Labelling Kit (Invitrogen, UK), following manufacturers instructions and as described previously (Douglas et al, 2004).
Test and reference DNAs (50 $\mu \mathrm{l}$ each) were combined and precipitated together with $100 \mu \mathrm{g}$ of human Cot1 DNA $\left(1 \mathrm{mg} \mathrm{ml}^{-1}\right.$; Invitrogen, UK) and $50 \mu$ l yeast tRNA ( $5 \mathrm{mg} \mathrm{ml}$; Invitrogen, UK). The DNA pellets were resuspended in $10 \mu \mathrm{l}$ of sterile water prior to being mixed with $10 \mu \mathrm{l}$ of microarray hybridisation solution (Amersham, UK) and $20 \mu \mathrm{l}$ of deionised formamide (Sigma, UK). The reconstituted probes were then incubated at $72^{\circ} \mathrm{C}$ for $15 \mathrm{~min}$ followed by $30 \mathrm{~min}$ at $37^{\circ} \mathrm{C}$. The probes were hybridised to BAC arrays and incubated for $48-72 \mathrm{~h}$ at $37^{\circ} \mathrm{C}$ in a humidified chamber. 
Slides were washed for $15 \mathrm{~min}$ at $42^{\circ} \mathrm{C}$ in $2 \times$ SSC, $0.1 \%$ SDS, $15 \mathrm{~min}$ at $42^{\circ} \mathrm{C}$ in $50 \%$ formamide $/ 2 \times \mathrm{SSC}, 30 \mathrm{~min}$ at $42^{\circ} \mathrm{C}$ in $2 \times$ SSC, $0.1 \%$ SDS and $15 \mathrm{~min}$ at room temperature in $0.2 \times$ SSC, before being dried by spinning in a centrifuge for $5 \mathrm{~min}$ at $150 \mathrm{~g}$.

\section{Data collection and analysis}

The slides were scanned using an Axon GenePix 4000A confocal scanner, each fluorescence signal was collected separately and quantified with the GenePix Pro 3.0 software (Axon Instruments, USA). Spots were defined by use of the automatic grid feature of the software and manually adjusted where necessary. The data was normalised and analysed using Normalise Suite v2.4 (Beheshti et al, 2003), regions of loss or gain were determined as those that were 2 s.d. above the mean baseline for each separate sample.

\section{RESULTS AND DISCUSSION}

The data presented here are based on the array CGH analysis of 18 UVMs. Figure 1 shows representative CGH profiles for chromosome 6,8 and 21 . Table 2 shows the chromosomal changes for all 18 tumours analysed, and Figure 2 shows the frequency of CNAs detected at the level of each chromosome arm. The overall frequency of alterations observed in the 18 tumours was higher than has been previously reported in metaphase CGH studies of UVM (Ghazvini et al, 1996; Tschentscher et al, 2000; Aalto et al, 2001; Naus et al, 2001). This reflects the greater sensitivity of array CGH.

Previous reports have stated that the most frequent anomaly in UVM is loss of an entire copy of chromosome 3 (Sisley et al, 1992; Wiltshire et al, 1993; White et al, 1998). In our analysis, however, the most common chromosomal changes identified were 8q gains (14/18; 78, 95\% confidence interval: $52-94 \%), 6 p$ gains $(12 / 18 ; 78$, $95 \%$ confidence interval: $41-87 \%)$, and monosomy 3 (10/18; 56 , 95\% confidence interval: $31-78 \%)$. Less common CNAs were loss of $1 \mathrm{p}(6 / 18 ; 33 \%), 6 \mathrm{q}(7 / 18 ; 39 \%)$ and $8 \mathrm{p}(8 / 18 ; 44 \%)$, and gain of $7 \mathrm{p}(5 / 18 ; 28 \%)$ and $21 \mathrm{q}(5 / 18 ; 28 \%)$.

Inspection of the CGH profiles of monosomy 3 and disomy 3 tumours delineated two tumour types; a division supported by hierarchical clustering of the CGH data (see Supplementary data) and published microarray expression data (Tschentscher et al, 2003). In all, 10 tumours had monosomy 3 and eight disomy 3 . Figure 2 shows the frequency of genomic imbalance, at the chromosome arm level, stratified by chromosome 3 status. Compared to disomy 3 melanomas, monosomy 3 tumours showed more frequent loss of chromosomal material from $1 \mathrm{p}, 6 \mathrm{q}$ and $8 \mathrm{p}$ in addition to gain of 7 and 21q. Furthermore, the regions of change in disomy 3 tumours, in some cases, involved less of the affected chromosomal arms than monosomy 3 tumours (Table 2). This probably reflects increase genomic instability in monosomy 3 tumours (Myatt et al, 2000).

Previously published analyses of chromosome 3 in UVM have shown that partial deletions of monosomy 3 are detectable in approximately $50 \%$ of tumours and have defined two minimum regions of loss, 3p25.1-p25.2 and 3q24-q26 (Tschentscher et al, 2001; Parrella et al, 2003). All the tumours we analysed with loss of chromosome 3 material showed loss of the entire chromosome, thus we were not able to further refine either of these regions of deletion.

Monosomy 3 has been hypothesised to represent an early event in tumourigenesis, defining a bificated tumour progression pathway (Parrella et al, 1999; Hoglund et al, 2004). In our study there was an inverse relationship between monosomy 3 and gain of $6 \mathrm{p}$ (Fishers exact test $P=0.06$ ). It has been proposed that at least two cytogenetic pathways of clonal evolution exist for UVMs, one initiated with monosomy 3 and one with gain of $6 \mathrm{p}$ (Hoglund et al, 2004).

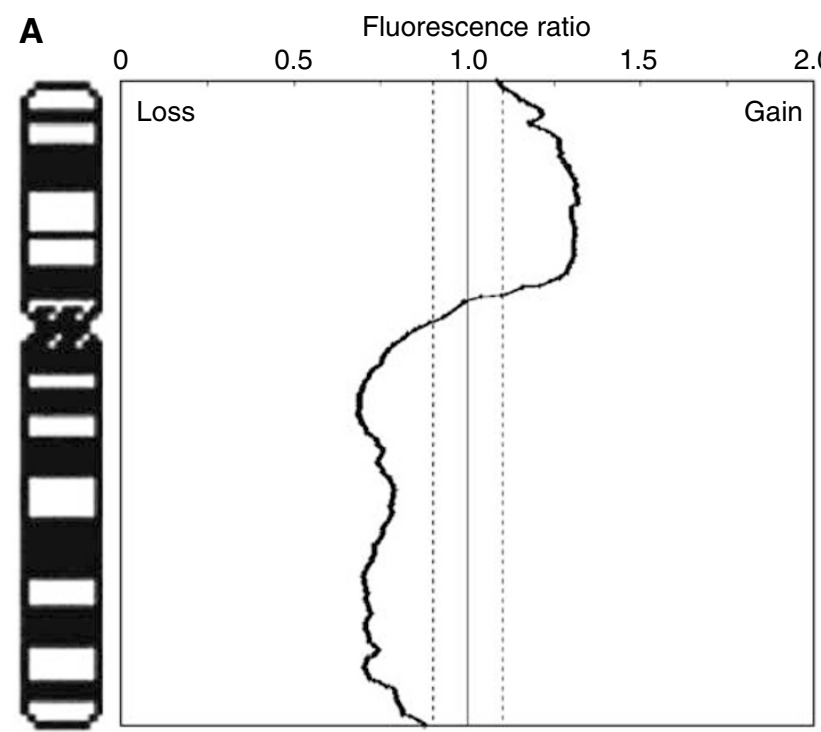

Chromosome 6 (tumour sample 24)

B

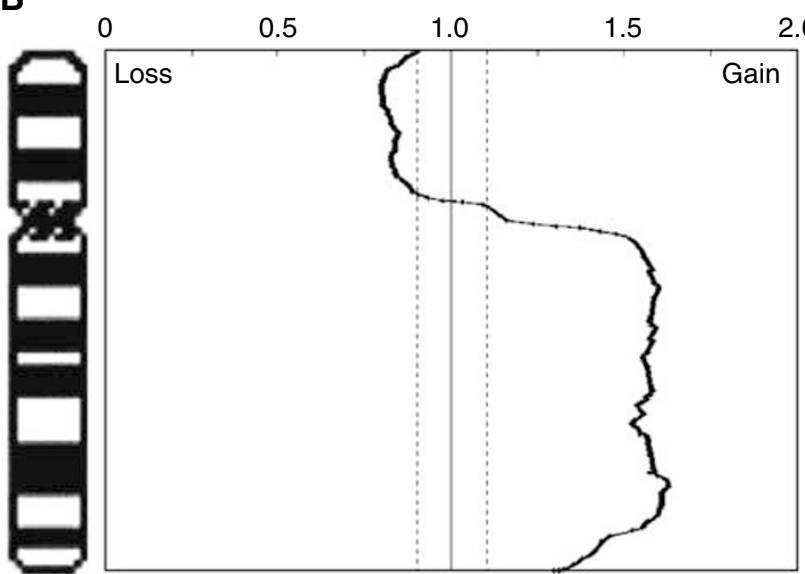

Chromosome 8 (tumour sample 44)

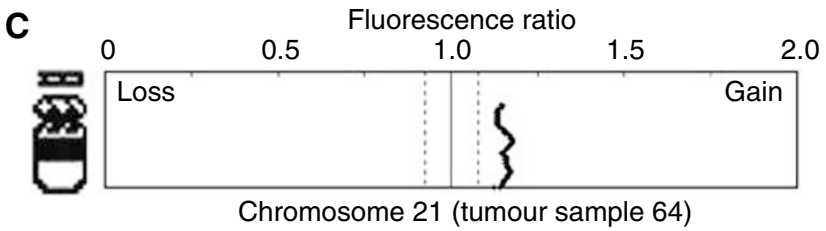

Figure I Examples of array CGH data, (A) 6p gain and 6q loss (tumour sample 24), (B) 8p loss and 8q gain (tumour sample 44 ) and $(\mathbf{C})$ gain of 21 (tumour sample 64). The data was normalised and analysed using Normalise Suite v2.4 (Beheshti et al, 2003), regions of loss (left of the central line) or gain (right of the central line) were determined as those that were 2 s.d. (denoted by dashed black or gray lines) from the mean baseline for each separate sample.

UVMs characterised by monosomy 3 are associated with a greater tumour size and a poor prognosis for survival (Prescher et al, 1996; Sisley et al, 1997; Scholes et al, 2003). Although our study did not permit survivorship associated with monosomy 3 to be formally assessed, it is noteworthy that six of the 10 patients with monosomy 3 tumours developed metastatic disease compared with only one of the eight patients with disomy 3 tumours (Fishers exact test $P=0.06$ ). In our study, excluding anomalies of chromosome 3, the frequency of CNAs were higher, albeit nonsignificantly, in the tumours with monosomy 3 than in 

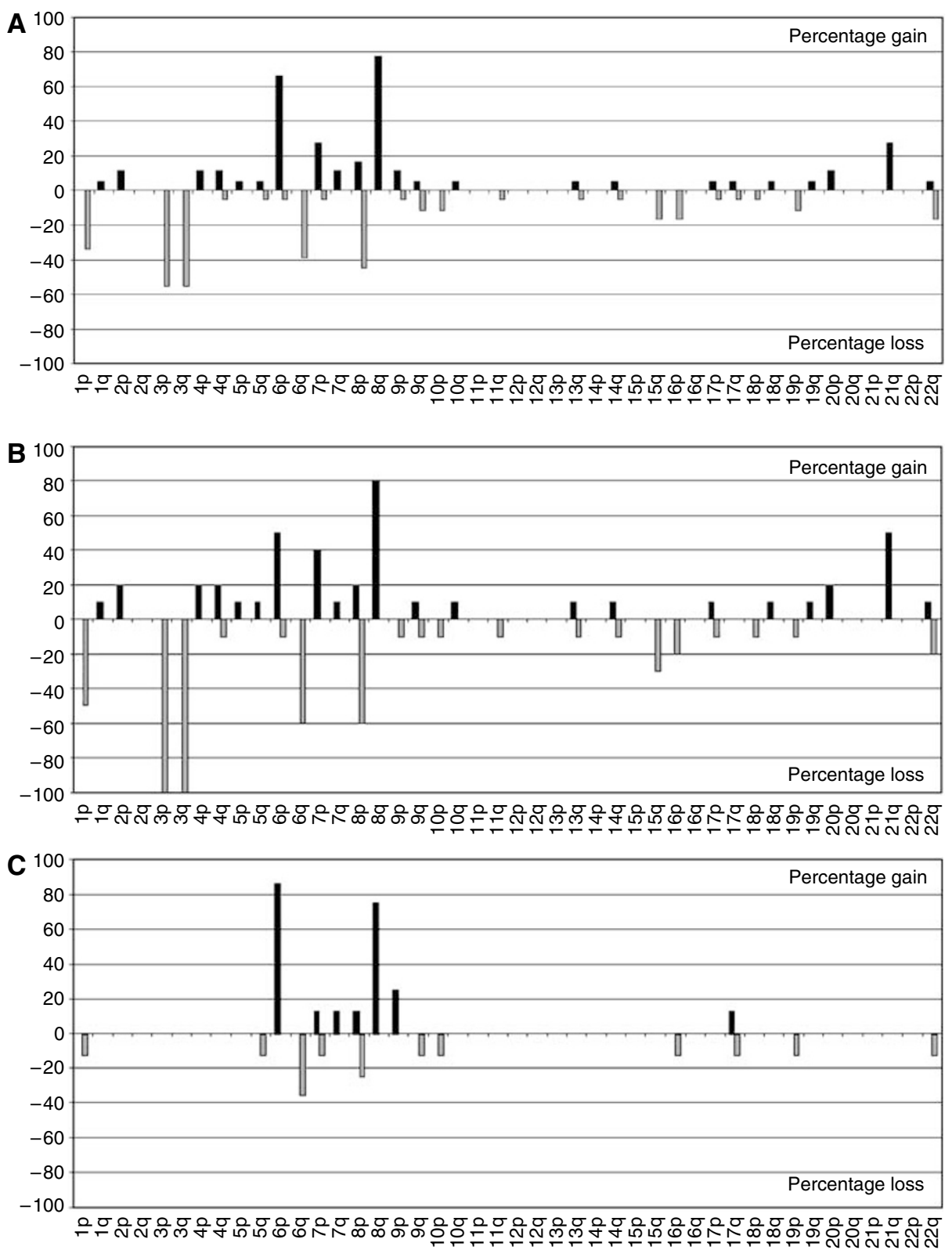

Figure 2 Summary of chromosomal losses and gains in $(\mathbf{A})$ all tumours $(n=18),(\mathbf{B})$ monosomy $3(n=10)$ and $(\mathbf{C})$ disomy $3(n=8)$ tumours Proportion of tumours of each type with gain and loss at the level of the chromosome arm are shown by black and grey bars, respectively.

tumours with disomy 3 (Mann-Whitney test, $P<0.10)$; 7.5 CNAs (range 2-20) and 3.5 CNAs (range 1-13) respectively. Recent work on other cancers has shown prognosis is worse when high rates of chromosome instability are a feature, probably a consequence of the accumulation of induced genetic alterations (Nakamura et al, 2003). This might explain the better prognosis observed for UVM patients with disomy 3 tumours. In our study tumours with monosomy 3 were larger than those with disomy 3 (Mann-Whitney test, $P<0.008$; median sizes $18.4 \mathrm{~mm}$ (range $16.2-20.9 \mathrm{~mm}$ ) and $13.9 \mathrm{~mm}$ (range $11.8-22.2 \mathrm{~mm}$, respectively) and after adjusting for tumour size there was little support for a relationship between monosomy 3 status and frequency of CNAs per se $(P=0.80)$. Although only a small number of tumours were analysed in our study this finding invites speculation that monosomy 3 may be a consequence of clonal selection during tumour progression.

To identify SORI at each region of CNA, genomic distances spanning regions of imbalance were determined separately for monosomy 3 and disomy 3 tumours, at the resolution of individual BAC clones. The data from tumours in each group were then compared and the SORI defined for each chromosome. The SORI involving at least two of the 10 monosomy 3 tumours or two of the eight disomy 3 tumours are shown in Table 3. The SORI data described here (Table 3 ) corroborate the previously identified regions of imbalance reported to be associated with UVMs (Aalto et al, 2001; Naus et al, 2001), specifically, 6p (6p25.1-p21.2), $6 \mathrm{q}(6 \mathrm{q} 16.2-\mathrm{q} 25.3)$ and $8 \mathrm{p}(8 \mathrm{p} 23.3-\mathrm{p} 11.23)$. Furthermore, our SORI data delineates a number of additional minimal regions of imbalance in monosomy 3 patients, several less than $30 \mathrm{Mb}$, as detailed in Table 3.

In addition to confirming and refining, at base pair resolution, a number of previously reported CNAs, the use of high-resolution array CGH has allowed us to accurately delineate (to within $1 \mathrm{Mb}$ ) a number of rarely reported chromosomal regions of abnormality in UVM. The minimum regions defined are likely to harbour genes important to the development of UVMs. 
Table 3 Smallest overlapping regions of imbalance found by array CGH for patients displaying (a) monosomy $3(n=10)$ and $(b)$ disomy 3 ( $n=8$ ), in addition, to the genes either over expressed or under expressed with in these regions

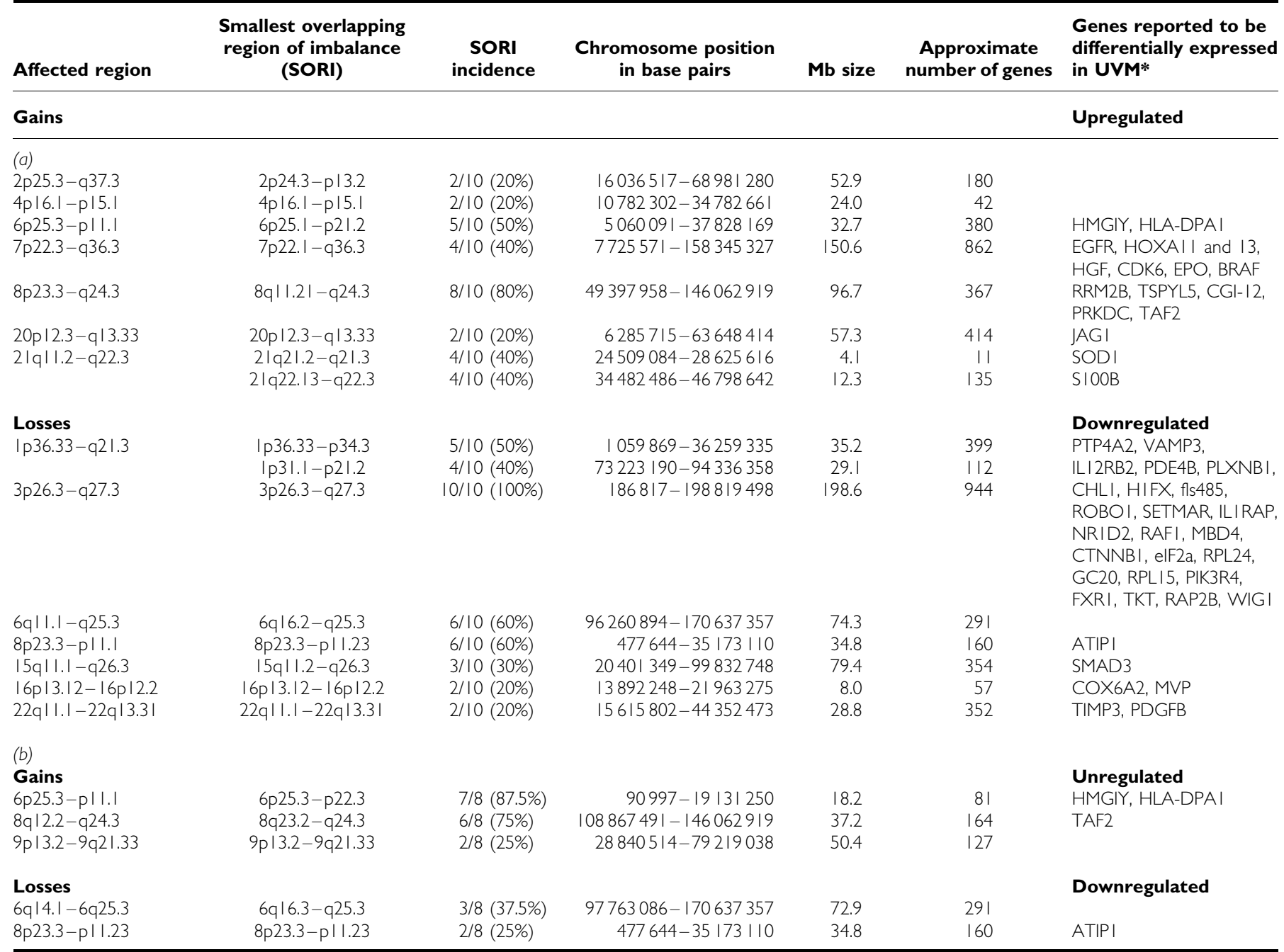

*Data extracted from Dunne et al, 1998; Hendrix et al, 1998; Hurks et al, 2000; Onken et al, 2004; Radosevich et al, 2004; Tschentscher et al, 2003; van der Velden et al, 2003; Van Ginkel et al, 1998; Zuidervaart et al, 2003.

\section{ACKNOWLEDGEMENTS}

We are grateful to the patients who participated in this study. The work was supported by Grants from Cancer Research UK. Simon Hughes was supported by a grant from the Wellcome Trust. We are grateful to Janet Shipley for her helpful criticisms and comments.

Supplemenatry information accompanies the paper on British Journal of Cancer website (http://www.nature.com/bjc).

\section{REFERENCES}

Aalto Y, Eriksson L, Seregard S, Larsson O, Knuutila S (2001) Concomitant loss of chromosome 3 and whole arm losses and gains of chromosome 1, 6 , or 8 in metastasizing primary uveal melanoma. Invest Ophthalmol Vis Sci 42: $313-317$

Beheshti B, Braude I, Marrano P, Thorner P, Zielenska M, Squire JA (2003) Chromosomal localization of DNA amplifications in neuroblastoma tumors using cDNA microarray comparative genomic hybridization. Neoplasia 5: 53-62

Bergman L, Seregard S, Nilsson B, Lundell G, Ringborg U, RagnarssonOlding B (2003) Uveal melanoma survival in Sweden from 1960-1998. Invest Ophthalmol Vis Sci 44: 2579-2583

Douglas EJ, Fiegler H, Rowan A, Halford S, Bicknell DC, Bodmer W, Tomlinson IP, Carter NP (2004) Array comparative genomic hybridiza- tion analysis of colorectal cancer cell lines and primary carcinomas. Cancer Res 64: 4817-4825

Dunne BM, McNamara M, Clynes M, Shering SG, Larkin AM, Moran E, Barnes C, Kennedy SM (1998) MDR1 expression is associated with adverse survival in melanoma of the uveal tract. Hum Pathol 29: 594-598

Fiegler H, Carr P, Douglas EJ, Burford DC, Hunt S, Scott CE, Smith J, Vetrie D, Gorman P, Tomlinson IP, Carter NP (2003) DNA microarrays for comparative genomic hybridization based on DOP-PCR amplification of BAC and PAC clones. Genes Chromosomes Cancer 36: $361-374$

Ghazvini S, Char DH, Kroll S, Waldman FM, Pinkel D (1996) Comparative genomic hybridization analysis of archival formalin-fixed paraffinembedded uveal melanomas. Cancer Genet Cytogenet 90: 95-101 
Hendrix MJ, Seftor EA, Seftor RE, Kirschmann DA, Gardner LM, Boldt HC, Meyer M, Pe'er J, Folberg R (1998) Regulation of uveal melanoma interconverted phenotype by hepatocyte growth factor/scatter factor (HGF/SF). Am J Pathol 152: $855-863$

Hoglund M, Gisselsson D, Hansen GB, White VA, Sall T, Mitelman F, Horsman D (2004) Dissecting karyotypic patterns in malignant melanomas: temporal clustering of losses and gains in melanoma karyotypic evolution. Int J Cancer 108: 57-65

Hurks HM, Metzelaar-Blok JA, Barthen ER, Zwinderman AH, De WolffRouendaal D, Keunen JE, Jager MJ (2000) Expression of epidermal growth factor receptor: risk factor in uveal melanoma. Invest Ophthalmol Vis Sci 41: $2023-2027$

McLean IW, Saraiva VS, Burnier Jr MN (2004) Pathological and prognostic of uveal melanomas. Can J Ophthalmol 39: 343-350

Myatt N, Aristodemou P, Neale MH, Foss AJ, Hungerford JL, Bhattacharya S, A Cree I (2000) Abnormalities of the transforming growth factor-beta pathway in ocular melanoma. J Pathol 192: 511-518

Nakamura H, Saji H, Idiris A, Kawasaki N, Hosaka M, Ogata A, Saijo T, Kato H (2003) Chromosomal instability detected by fluorescence in situ hybridization in surgical specimens of non-small cell lung cancer is associated with poor survival. Clin Cancer Res 9: 2294-2299

Naus NC, van Drunen E, de Klein A, Luyten GP, Paridaens DA, Alers JC, Ksander BR, Beverloo HB, Slater RM (2001) Characterization of complex chromosomal abnormalities in uveal melanoma by fluorescence in situ hybridization, spectral karyotyping, and comparative genomic hybridization. Genes Chromosomes Cancer 30: 267-273

Onken MD, Worley LA, Ehlers JP, Harbour JW (2004) Gene expression profiling in uveal melanoma reveals two molecular classes and predicts metastatic death. Cancer Res 64: 7205-7209

Parrella P, Fazio VM, Gallo AP, Sidransky D, Merbs SL (2003) Fine mapping of chromosome 3 in uveal melanoma: identification of a minimal region of deletion on chromosomal arm 3p25.1-p25.2. Cancer Res 63: $8507-8510$

Parrella P, Sidransky D, Merbs SL (1999) Allelotype of posterior uveal melanoma: implications for a bifurcated tumor progression pathway. Cancer Res 59: $3032-3037$

Prescher G, Bornfeld N, Hirche H, Horsthemke B, Jockel KH, Becher R (1996) Prognostic implications of monosomy 3 in uveal melanoma. Lancet 347: 1222 - 1225

Radosevich M, Song Z, Gorga JC, Ksander B, Ono SJ (2004) Epigenetic silencing of the CIITA gene and posttranscriptional regulation of class II MHC genes in ocular melanoma cells. Invest Ophthalmol Vis Sci 45: 3185-3195

Scholes AG, Damato BE, Nunn J, Hiscott P, Grierson I, Field JK (2003) Monosomy 3 in uveal melanoma: correlation with clinical and histologic predictors of survival. Invest Ophthalmol Vis Sci 44: 1008-1011
Sisley K, Cottam DW, Rennie IG, Parsons MA, Potter AM, Potter CW, Rees RC (1992) Non-random abnormalities of chromosomes 3, 6, and 8 associated with posterior uveal melanoma. Genes Chromosomes Cancer 5: $197-200$

Sisley K, Rennie IG, Parsons MA, Jacques R, Hammond DW, Bell SM, Potter AM, Rees RC (1997) Abnormalities of chromosomes 3 and 8 in posterior uveal melanoma correlate with prognosis. Genes Chromosomes Cancer 19: $22-28$

Stang A, Parkin DM, Ferlay J, Jockel KH (2005) International uveal melanoma incidence trends in view of a decreasing proportion of morphological verification. Int J Cancer 114: 114-123

Tschentscher F, Husing J, Holter T, Kruse E, Dresen IG, Jockel KH, Anastassiou G, Schilling H, Bornfeld N, Horsthemke B, Lohmann DR, Zeschnigk M (2003) Tumor classification based on gene expression profiling shows that uveal melanomas with and without monosomy 3 represent two distinct entities. Cancer Res 63: 2578-2584

Tschentscher F, Prescher G, Horsman DE, White VA, Rieder H, Anastassiou G, Schilling H, Bornfeld N, Bartz-Schmidt KU, Horsthemke B, Lohmann DR, Zeschnigk M (2001) Partial deletions of the long and short arm of chromosome 3 point to two tumor suppressor genes in uveal melanoma. Cancer Res 61: 3439-3442

Tschentscher F, Prescher G, Zeschnigk M, Horsthemke B, Lohmann DR (2000) Identification of chromosomes 3, 6, and 8 aberrations in uveal melanoma by microsatellite analysis in comparison to comparative genomic hybridization. Cancer Genet Cytogenet 122: 13-17

van der Velden PA, Zuidervaart W, Hurks MH, Pavey S, Ksander BR, Krijgsman E, Frants RR, Tensen CP, Willemze R, Jager MJ, Gruis NA (2003) Expression profiling reveals that methylation of TIMP3 is involved in uveal melanoma development. Int J Cancer 106: $472-479$

Van Ginkel PR, Gee RL, Walker TM, Hu DN, Heizmann CW, Polans AS (1998) The identification and differential expression of calcium-binding proteins associated with ocular melanoma. Biochim Biophys Acta 1448: $290-297$

White VA, McNeil BK, Horsman DE (1998) Acquired homozygosity (isodisomy) of chromosome 3 in uveal melanoma. Cancer Genet Cytogenet 102: $40-45$

Wiltshire RN, Elner VM, Dennis T, Vine AK, Trent JM (1993) Cytogenetic analysis of posterior uveal melanoma. Cancer Genet Cytogenet 66: $47-53$

Zuidervaart W, van der Velden PA, Hurks MH, van Nieuwpoort FA, Out-Luiting CJ, Singh AD, Frants RR, Jager MJ, Gruis NA (2003) Gene expression profiling identifies tumour markers potentially playing a role in uveal melanoma development. $\mathrm{Br} J$ Cancer 89: $1914-1919$ 